\title{
Studi perbandingan adaptasi Kura-Kura Pipi Putih (Siebenrockiella crassicollis) jantan dan betina di area Kolam Konservasi Universitas Bengkulu
}

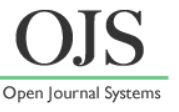

\author{
Julita Pasaribu $^{1 *}$, Aceng Ruyani ${ }^{1}$, Hery Suhartoyo ${ }^{2}$ \\ ${ }^{1}$ Program Studi Pascasarjana Pendidikan IPA Universitas Bengkulu \\ ${ }^{2}$ Jurusan kehutanan, Fakultas Pertanian, Universitas Bengkulu \\ *Email: pasaribu_julita@yahoo.com
}

DOI: https://doi.org/10.33369/pendipa.v3i1.6923

\begin{abstract}
[Adaptation study of Pipi Putih (Siebenrockiella crassicolli) sexes in conservation pond at University of Bengkulu]. This study aims to compare the adaptability of Pipi Putih turtles (Siebenrockiella crassicollis) of males and females in the conservation pond area of University of Bengkulu (UNIB). Nine S.crassicollis were kept individually in a cage, consisting of three space at three different point. S.crassicollis were fed with kangkung (Ipomea aquatica) as much as $10 \%$ of their body weight. Growth parameters was collected every week for six weeks : (a) weight gain (WG); (b) thick growth of body (TGB); (c) growth of carapace length $(G C L),(d)$ growth of carapace width $(G C W) ;(e)$ growth of plastron length $(G P L)$ and $(f)$ plastron width growth $(P W G)$ The measurement results show: $(a)$ WG: male $=3.50 \%$, female $=2.01 \%(b)$ TGB: male $=0.30 \%$, female $=-0.05 \% ;(c)$ GCL: male $=0.16$, female $=0.26 \%$, (d) GCW : male $=0.566 \%$, female $=0.47 \%(e)$ GPL: male $=0.28 \%$, female $=0,27 \%$ and $(f)$ $P W G:$ male $=1.25 \%$, female $=1.16 \%$. Mean turtle growth percentage of all indicators: male $S$. crassicollis $=0.01 \%$ and $0.69 \%$ for female S. crassicollis. We concluded that the adaptability of male $S$. crassicollis turtles was higher than for female $S$. crassicollis.
\end{abstract}

Keywords: Conservation; Siebenrockiella crassicollis; turtle; adaptation.

(Received August 16, 2018; Accepted January 19, 2019; Published February 26, 2019)

\begin{abstract}
ABSTRAK
Penelitian ini bertujuan untuk membandingkan kemampuan adaptasi kura-kura pipi putih (Siebenrockiella crassicollis) jantan dan betina di area kolam konservasi Universitas Bengkulu (UNIB). Sembilan ekor S.crassicollis dipelihara secara individu di dalam kerambah. Terdapat tiga kerambah yang diletakkan pada tiga titik berbeda. Kangkung (Ipomea aquatica) merupakan pakan yang diberikan sebanyak $10 \%$ dari berat badan. Pengambilan data dilakukan sekali seminggu selama enam pekan. Parameter pertumbuhan yang diamati adalah (a) pertumbuhan berat badan (PBB); (b) pertumbuhan tebal badan (PTB); (c) pertumbuhan panjang karapaks (PPK), (d) pertumbuhan lebar karapaks (PLK); (e) pertumbuhan panjang plastron (PPP) dan (f) pertumbuhan lebar plastron (PLP). Hasil pengukuran menunjukkan: (a) PBB: jantan $=3,50 \%$, betina $=2,01 \%$ (b) PTB: jantan $=0,30 \%$, betina $=-0,05 \%$; (c) PPK : jantan $=0,16$, betina $=0,26 \%$, (d) PLK : jantan $=0,566 \%$, betina $=0,47 \%$ (e) PPP: jantan $=0,28 \%$, betina $=0,27 \%$ dan (f) PLP: jantan $=1,25 \%$, betina $=1,16 \%$. Rata-rata persen pertumbuhan kura-kura dari seluruh indikator: S.crassicollis jantan $=0,01 \%$ dan $0,69 \%$ untuk S.crassicollis betina. Berdasarkan data yang diperoleh,disimpulkan bahwa tingkat adaptasi kura-kura S.crassicollis jantan lebih tinggi daripada $S$. crassicollis betina.
\end{abstract}

Kata kunci: Konservasi; Siebenrockiella crassicollis; kura-kura; adaptasi. 


\section{PENDAHULUAN}

\begin{tabular}{rrrr}
\multicolumn{2}{c}{ Indonesia memiliki keanekaragaman } \\
hayati yang & melimpah, khususnya
\end{tabular} reptil.Berdasarkan koleksi herpetofauna dari berbagai daerah di Indonesia yang tersimpan di Museum Zoologi Bogor dapat diketahui bahwa Indonesia memiliki sekitar 1.500 jenis reptil (Tjakrawidjaja,, 2010). Kekayaan reptil di Indonesia terancam menurun.Meskipun sudah ada kerangka hukum dan peraturan turunan yang menyeluruh dan dirancang untuk mencegah kerugian, namun para pemburu gelap, pedagang, pengirim dan pembeli satwa liar masih dapat menghindari proses hukum berupa penangkapan, penyidikan, dan tuntutan dengan memanfaatkan keterbatasan kapasitas dari polisi hutan, polisi dan sistem peradilan dalam menegakkan peraturan yang berlaku, dan dengan memanfaatkan sejumlah celah hukum yang masih ada. Maka dari itu, diperlukan penanganan guna mecegah terancamnya keberadaan keanegaraman tersebut, salah satu langkah yang dilakukan adalah dengan melakukan konservasi.

Pendidikan adalah sarana yang tepat untuk mencapai tujuan konservasi.Di Provinsi Bengkulu, kampus yang melakukan kegiatan konservasi adalah Universitas Bengkulu (UNIB), yang secara spesifik melakukan konservasi pada kura-kura Sumatera. S. crassicollis adalah salah satu jenis kura di provinsi Bengkulu yang saat ini terdata dalam daftar apendiks II CITES pada tahun 2017 (CITES, 2017). Habitat kura-kura Pipi Putih cukup bervariasi, yaitu hutan yang masih bagus sampai pada hutan yang sudah rusak asalkan terdapat sumber air tawar yang permanen; di Taman Nasional Ujung Kulon, $S$. crassicollis dijumpai di sungai-sungai kecil berbatu yang berarus deras di dalam hutan primer (Kurniati dkk, 2000). Hal ini menjadi dasar dalam upaya melakukan konservasi terhadap jenis kuraS.crassicollis. Salah satu area Konservasi UNIB adalah Kolam Konservasi FKIP untuk konservasi kura kura jenis Pipi Putih (Siebenrockiella crassicollis).

Rendahnya kesadaran masyarakat terhadap perilaku melindungi dan mengonservasi adalah salah satu penyebab terancamnya keberadaan spesies ini. Kura-kura kemungkinan besar akan punahakibat pemanfaatan yang berlebihan terutama karena kura-kura diekspor dalam jumlah yang besar dalam setiap bulannya (meliputi puluhan ribu ton atau puluhan ribu ekor) (Iskandar, 2000).

Penelitian mengenai keberadaan $S$. Crassicollis telah dilakukan oleh Ruyani (2015), yang menyatakan air kolam kampus UNIB menunjukkan daya aklimatisasi yang baik bagi kura Pipi putih. Kemudian, penelitian juga telah dilakukan Erma (2016) yang membandingkan jenis dan bobot serta perbandingan habitat (Kolam Pipi Putuh dan SBIH) kura-kura terhadap aklimatisasi. Hasil penelitian ini dikembangkan menjadi bahan ajar di kelas XII. Selanjutnya, penelitian juga dilakukan oleh Pasaribu dkk (2017) langsung di area kolam konservasi FKIP UNIB dan hasilnya menunjukkan bahwa secara umum kura-kura mampu beradaptasi di area tersebut.Berdasarkan penelitian sebelumnya, belum ada peneliti yang membandingkan kemampuan adaptasi antara $S$. crassicollis jantan dan betina.Penelitian kali ini akan membahas perbandingan kemampuan adaptasi S. crassicollis jantan dan betina berdasarkan indikator pertumbuhan yang diamati.

\section{METODE PENELITIAN}

\section{Waktu dan Tempat Penelitian}

Penelitian dilakukan selama enam pekan dari bulan Agustus hingga Oktober 2017 di Area Kolam Konservasi FKIP Universitas Bengkulu.

\section{Alat dan Bahan}

Alat yang digunakan adalah jaring, tali, ember, timbangan, higrometer, Thermometer, pipa paralon, alat tulis, kamera, mistar, turtlnet, pisau, meteran, jangka sorong, kamera.

Bahan yang digunakan dalam penelitian ini adalah 9 ekor kura S.crassicollis dengan kangkung (Ipomoea aquatica) sebagai pakannya.

\section{Pengumpulan data \\ Pengukuran pertumbuhan dilakukan setiap satu pekan sekali, kura-kura diambil dari masing- masing kerambah. Indikator pertumbuhan yang diamati adalah: pengukuran berat badan, pengukuran tebal badan, pengukuran panjang karapaks, pengukuran panjang plastron, pengukuran lebar karapaks, pengukuran lebar plastron.}




\section{Analisis data}

Pertumbuhan berat badan, panjang dan lebar karapaks, panjang dan lebar plastron, serta tebal badan diperoleh dari data akhir dikurangi data awal (Waldbaver dalam Melinda, 2007), dengan rumus sebagai berikut:

a. Pertumbuhan berat badan (PBB)

Pertumbuhan berat badan $=$ berat badan akhir berat badan awal

$\%$ PBB = Pertumbuhan berat badan $\times 100 \%$

b. Pertumbuhan panjang karapaks (PPK)

Pertumbuhan panjang karapaks $=$ panjang karapaks akhir - panjang karapaks awal

$\% \mathrm{PKK}=$ Pertumbuhan panjang karapaks x $100 \%$

c. Pertumbuhan lebar karapaks (PLK)

Pertumbuhan lebar karapaks = lebar karapaks akhir - lebar karapaks awal

$\%$ PLK = Pertumbuhan lebar karapaks x 100\%

d. Pertumbuhan panjang plastron (PPP)

Pertumbuhan panjang plastron $=$ panjang plastron akhir - panjang plastron awal

$\% \mathrm{PPP}=$ Pertumbuhan panjang plastron $\mathrm{x} 100 \%$

e. Pertumbuhan lebar plastron (PLP)

Pertumbuhan lebar plastron $=$ lebar plastron akhir - lebar plastron awal.

$\%$ PPP $=$ Pertumbuhan lebar plastron $\mathrm{x} 100 \%$

f. Pertumbuhan tebal badan (PTB)

Pertumbuhan tebal badan $=$ tebal badan akhir tebal badan awal

$\%$ PTB $=$ Pertumbuhan tebal badan $\times 100 \%$

\section{HASIL DAN PEMBAHASAN}

\section{Pertumbuhan berat badan}

Pertumbuhan berat badan kura-kura jantan (ठ) pertumbuhan berat kadannya sebesar 3,50\% dan kura-kura betina (\%) sebesar 2,01\%. Dari data tersebut terlihat bahwa pertumbuhan berat badan pada $S$. crassicollis jantan lebih besar daripada kura-kura dengan jenis kelamin betina.Persen rata-rata pertumbuhan berat badan selama enam pekan dapat dilihat juga pada Gambar 1.

Tabel 1. Rata-rata pertumbuhan berat badan

\begin{tabular}{|c|c|c|c|c|c|c|c|c|}
\hline \multirow{2}{*}{$\frac{01}{\delta}$} & \multirow[b]{2}{*}{$\mathrm{N}$} & \multicolumn{7}{|c|}{ PEKAN KE- dalam \% } \\
\hline & & I & II & III & IV & V & VI & rata- \\
\hline 6 & 4 & 3,15 & 3,84 & 4,20 & 2,80 & 4,06 & 2,94 & 3,50 \\
\hline $0^{\circ}$ & 5 & 1,74 & 3,17 & 3,83 & 0,44 & 2,74 & 0,15 & 2,01 \\
\hline
\end{tabular}

https://ejournal.unib.ac.id/index.php/pendipa

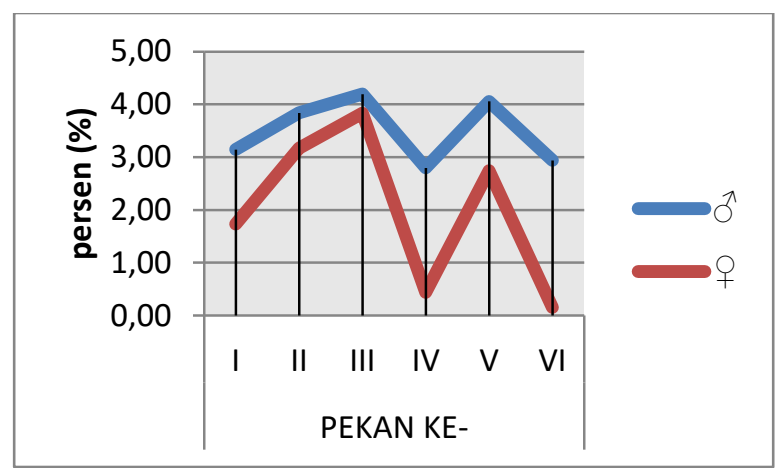

Gambar 1. Rata-rata Pertumbuhan Berat Badan

Dari Gambar 1 terlihat bahwa pertumbuhan berat badan mengalami fluktuasi yang sifatnya reversible. Pertumbuhan berat badan mengalami peningkatan pada kura-kura berjenis kelamin jantan.Hal ini dipengaruhi oleh berbagai faktor, baik faktor eksternal atau pun internal. Hal ini sesuai dengan pernyataan Angiletta (2014), faktor yang mempengaruhi pertumbuhan berat badan ini dapat berupa makanan yang dikonsumsi maupun kondisi lingkungan tempat tinggalnya. Sedangkan faktor yang dapat menyebabkan menurunnya berat badan disebabkan oleh penggunaan energi yang cukup besar sebagai akibat dari proses adaptasi pada lingkungan yang baru. Maka, penurunan dan peningkatan berat badan adalah merupak respon adaptasi kura-kura di kolam konservasi.

\section{Pertumbuhan tebal badan}

Berdasarkan Tabel 2, terlihat rata-rata pertumbuhan tebal badan pada $S$. crassicollis jantan adalah 0,30 yang berarti lebih tinggi dibandingkan rata-rata pertumbuhan $S$. crassicollis betina yaitu sebesar $-0,05 \%$. Hal ini berbanding lurus dengan pertumbuhan berat badan, dimana pertumbuhan berat badan pada kura-kura juga lebih tinggi dibandingkan $S$. crassicollis betina. Data pertumbuhan tebal badan S.crassicollis setiap pekan selama enam pekan pengamatan dapat dilihat pada Gambar 2.

Tabel 2. Rata-rata pertumbuhan tebal badan

\begin{tabular}{|c|c|c|c|c|c|c|c|c|}
\hline \multirow[b]{2}{*}{$9 / 8$} & \multirow[b]{2}{*}{$\mathrm{N}$} & \multicolumn{7}{|c|}{ PEKAN KE- dalam \% } \\
\hline & & I & II & IIII & IV & V & VI & $\begin{array}{l}\text { rata- } \\
\text { rata }\end{array}$ \\
\hline 8 & 4 & $-0,38$ & 0,35 & 0,40 & 0,37 & 0,37 & 0,72 & 0,30 \\
\hline 9 & 5 & 0,00 & 0,01 & 0,01 & $-0,30$ & 0,31 & $-0,29$ & $-0,05$ \\
\hline
\end{tabular}




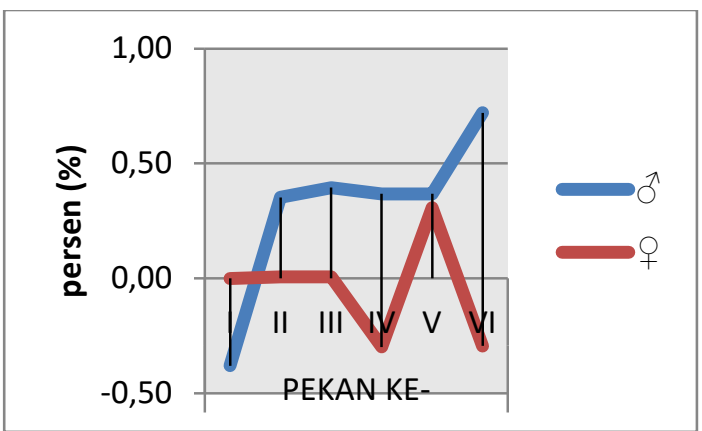

Gambar 2. Rata-rata Pertumbuhan Tebal Badan

Berdasarkan Gambar 2, dapat terlihat fluktuasi pertumbuhan tebal badan kura-kura selama enam pekan pengamatan. Pertumbuhan tebal badan juga dipengaruhi oleh pertumbuhan berat badan.Maka pertumbuhan tebal badan yang dipengaruhi oleh berat badan juga merupakan pengaruh dari makanan kura-kura. Hal ini sesuai dengan pernyataan Effendie, menurut Effendie (1997) faktor luar yang mempengaruhi pertumbuhan yaitu makanan, suhu, oksigen terlarut dan faktor kualitas air.Makanan digunakan oleh tubuh untuk metabolisme dasar, pergerakan, produksi organ seksual, perawatan bagian tubuh atau mengganti sel yang rusak. Maka, tebal badan yang mengalami fluktuatif merupakan rangkaian dari adaptasi kura-kura untuk beradaptasi.

\section{Pertumbuhan Panjang Karapaks}

Pertumbuhan panjang karapaks adalah bersifat irreversibble, yaitu tidak dapat kembali. Hal ini terlihat jelas pada grafik tidak ada penurunan grafik pada indikatorpanjang karapaks, Pertumbuhan kura-kura dipengaruhi oleh kandungan gizi pakan. Hal ini juga dinyatakan oleh Melinda (2007) bahwa kandungan gizi pakan yang seimbang terutama yang banyak mengandung protein yang diberikan pada kura-kura akan mengalami peningkatan pertumbuhan.

Tabel 3 Rata-rata pertumbuhan panjang karapaks

\begin{tabular}{|c|c|c|c|c|c|c|c|c|}
\hline \multirow{2}{*}{$\frac{0 / 1}{0}$} & \multirow[b]{2}{*}{$\mathrm{N}$} & \multicolumn{7}{|c|}{ PEKAN KE- dalam \% } \\
\hline & & I & ॥ & III & IV & V & $\mathrm{Vl}$ & $\begin{array}{l}\text { rata- } \\
\text { rata }\end{array}$ \\
\hline$\delta$ & 4 & $\begin{array}{c}0,162 \\
5\end{array}$ & $\begin{array}{c}0,162 \\
5\end{array}$ & $\begin{array}{c}0,162 \\
5\end{array}$ & $\begin{array}{c}0,162 \\
5\end{array}$ & $\begin{array}{c}0,162 \\
5\end{array}$ & $\begin{array}{c}0,162 \\
5\end{array}$ & 0,16 \\
\hline 0 & 5 & 0,124 & 0,124 & 0,242 & 0,366 & 0,366 & 0,366 & 0,26 \\
\hline
\end{tabular}

Bersadarkan Tabel 3, dapat diamati bahwa rata-rata pertumbuhan panjang karapaks selama enam pekan pada S. crassicollis betina lebih tinggi dibandingkan $S$. crassicollis jantan. Dapat dilihat bahwa rata-rata pertumbuhan panjang karapaks pada $S$. crassicollis jantan sebesar 0,16 lebih rendah dibandingkan $S$. crassicollis betina, yaitu $0,26 \%$. Data rata-rata persen pertumbuhan panjang karapaks setiap pekan pengamatan selama enam pekan dapat dilihat pada Gambar 3:

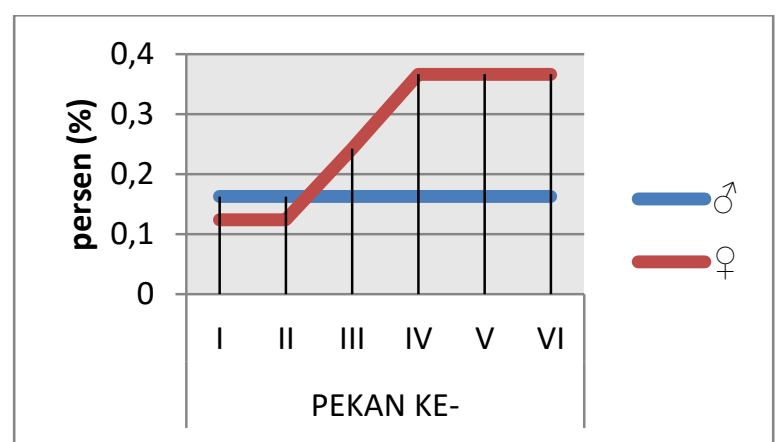

Gambar 3 Rata-rata Pertumbuhan Panjang Karapaks

\section{Pertumbuhan lebar karapaks}

Berdasarkan Tabel 4 terlihat data hasil pengamatan terhadap persen rata-rata pertumbuhan lebar karapaks selama enam pekan.Berdasrakan rata-rata yang diperoleh $S$. crassicollis jantan mengalami pertumbuhan lebar karapaks yang lebih tinggi dari S. crassicollis betina. Rata-rata pertumbuhan lebar karapaks pada $S$. crassicollis jantan sebesar $0,56 \%$ dan rata-rata persen pertumbuhan $S$. crassicollis betina sebesar $0,47 \%$. Data rata-rata persen pertumbuhan lebar karapaks setiap pekan pengamatan selama enam pekan dapat dilihat pada Gambar 4. Berdasarkan Gambar 4, terlihat bahwa pertumbuhan lebar karapaks bersifat irreversible dan tidak mengalami fluktuatif. Pertumbuhan lebar karapaks memerlukan waktu yang lama dan tidak mengalami peningkatan dan penurunan seperti pada berat badan dan tebal badan. Seperti yang telah disebutkan sebelumnya, bahwa pertumbuhan dipengaruhi oleh jenis pakan dan gizi.Maka, hal ini juga mempengaruhi pertumbuhan lebar dan panjang karapaks.Hal ini sesuai dengan pernyataan Wardiatno dkk (2009) berat dapat dianggap sebagai fungsi panjang, tetapi hubungan yang terdapat pada setiap hewan sebenarnya berbedabeda dikarenakan bentuk dan panjang tiap hewan 
tersebut berbeda-beda antara satu dengan lainnya.

Tabel 4 Rata-rata pertumbuhan lebar karapaks

\begin{tabular}{|c|c|c|c|c|c|c|c|c|}
\hline \multirow{2}{*}{$\% / \delta$} & \multirow{2}{*}{$\mathrm{N}$} & \multicolumn{7}{|c|}{ PEKAN KE- dalam \% } \\
\cline { 3 - 9 } & & I & II & III & IV & V & VI & $\begin{array}{c}\text { rata- } \\
\text { rata }\end{array}$ \\
\hline ర & 4 & 0,40 & 0,60 & 0,60 & 0,60 & 0,60 & 0,60 & 0,56 \\
\hline$\underline{Q}$ & 5 & 0,34 & 0,34 & 0,50 & 0,50 & 0,50 & 0,67 & 0,47 \\
\hline
\end{tabular}

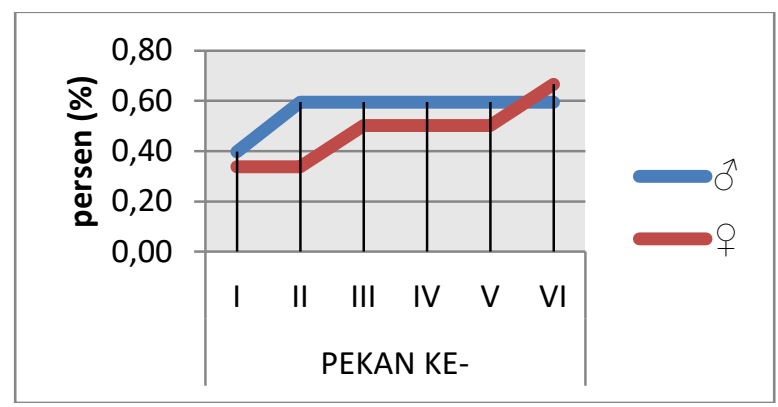

Gambar 4 Rerata Pertumbuhan Lebar Karapaks

\section{Pertumbuhan panjang plastron}

Berdasarkan Tabel 5, terlihat bahwa ratarata persen pertumbuhan panjang karapaks tidak terdapat perbedaan yang nyata antara $S$. crassicollis jantan dan betina. Rata-rata persen pertumbuhan panjang plastron $S$. crassicollis jantan sebesar $0,28 \%$ dan rata-rata persen pertumbuhan panjang plastron $S$. crassicollis betina sebesar $0,27 \%$. Data rata-rata persen pertumbuhan panjang plastron setiap pekan pengamatan selama enam pekan dapat dilihat pada Gambar 5.

Tabel 5 Rata-rata pertumbuhan panjang plastron

\begin{tabular}{|c|c|c|c|c|c|c|c|c|}
\hline \multirow[b]{2}{*}{$0 / \delta$} & \multirow[b]{2}{*}{$\mathrm{n}$} & \multicolumn{7}{|c|}{ PEKAN KE- dalam $\%$} \\
\hline & & I & ॥ & III & IV & V & $\mathrm{VI}$ & rata- \\
\hline 8 & 4 & 0,19 & 0,19 & 0,19 & 0,37 & 0,37 & 0,37 & 0,28 \\
\hline 0 & 5 & 0,16 & 0,16 & 0,33 & 0,33 & 0,33 & 0,33 & 0,27 \\
\hline
\end{tabular}

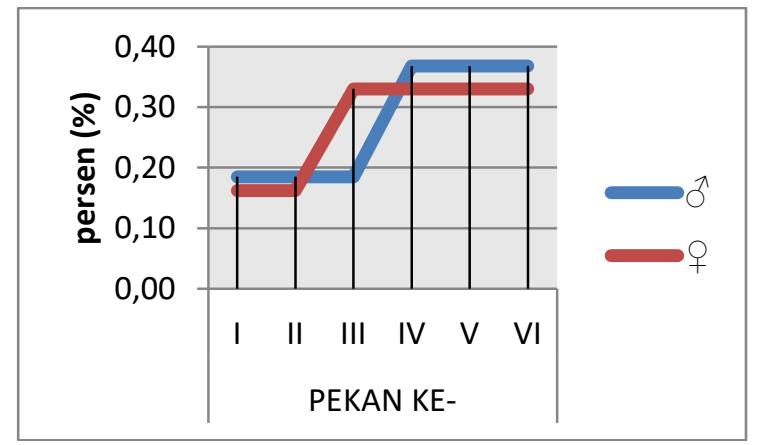

Gambar 5 Rerata Pertumbuhan Panjang Plastron
Berdasarkan Gambar 5, dengan jelas terlihat bahwa peningkatan pertumbuhan panjang plastron untuk $S$. crassicollis jantan dan betina. Terlihat bahwa pertumbuhan panjang plastron bersifat irreversibel.Sama seperti lebar karapaks pertumbuhan panjang karapaks berjalan lambat dan irreversible yang dipengaruhi oleh faktor eksternal dan internal.

\section{Pertumbuhan lebar Plastron}

Berdasarkan Tabel 6, terlihat rata-rata persen pertumbuhan lebar karapaks $S$. crassicollis jantan dan betina selama enam pekan pengamatan. Rata-rata $S$. crassicollis jantan sebesar 1,25 yang lebih besar dari rata-rata $S$. crassicollis betina, yaitu $1,16 . \%$. Data rata-rata persen pertumbuhan lebar plastron setiap pekan pengamatan selama enam pekan dapat dilihat pada Gambar 6.

Tabel 6 Rata-rata pertumbuhan lebar plastron

\begin{tabular}{|c|c|c|c|c|c|c|c|c|}
\hline \multirow{2}{*}{$\mathscr{f} / \delta$} & \multirow{2}{*}{$\mathrm{n}$} & \multicolumn{7}{|c|}{ PEKAN KE- dalam \% } \\
\cline { 3 - 9 } & & $\mathrm{I}$ & II & III & IV & V & VI & $\begin{array}{c}\text { rata- } \\
\text { rata }\end{array}$ \\
\hline$\delta$ & 4 & 0,73 & 1,21 & 1,21 & 1,45 & 1,45 & 1,45 & 1,25 \\
\hline$\underline{0}$ & 5 & 0,42 & 1,03 & 1,23 & 1,42 & 1,42 & 1,42 & 1,16 \\
\hline
\end{tabular}

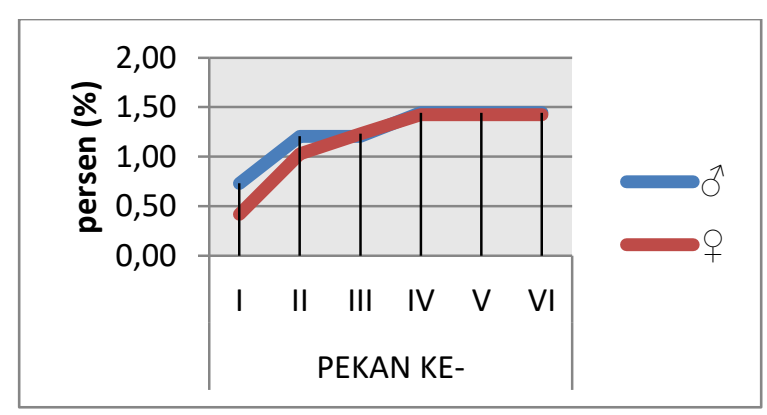

Gambar 6 Rerata Pertumbuhan Lebar Plastron

Dari Gambar 6 terlihat bahwa pertumbuhannya meningkat lalu konstan. Hal ini membuktikan bahwa pertumbuhan lebar plastron, sama halnya dengan panjang dan lebar karapaks serta panjang plastron yang bersifat irreversible. Secara umum, pertumbuhan kura-kura berjalan sangat lambat, namun berdasarkan hasil pengukuran terhadap pertumbuhan irreversibel selama enam pekan di Kolam Konservasi UNIB, kura-kura dapat berdaptasi. Menurut Casdika (1998), peningkatan laju pertumbuhan lebar karapas dapat disebabkan oleh nilai oksigen terlarut yang cukup tinggi yang memperlancar sirkulasi udara dalam air. 
Rata-rata persen pertumbuhan S. crassicollis

Tabel 7 memperlihatkan rata-rata pertumbuhan selama enam pekan baik pertumbuhan reversibel (berat badan dan tebal badan), dan irreversible (panjang dan lebar karapaks, serta panjang dan lebar plastron) berdasarkan jenis kelamin.Secara keseluruhan pertumbuhan selama enam pekan, rata-rata persen pertumbuhan yang paling tinggi adalah kura-kura dengan jenis kelamin jantan. Hal ini juga dibuktikan dari data pada Tabel 4.8, terlihat rata-rata persen pertumbuhan selama enam pekan tertinggi adalah sebesar 1,01 pada $S$. crassicollis jantan. Data rata-rata pertumbuhan kura-kura selama enam pekan juga dapat dilihat pada Gambar 7.

Tabel 7 Rerata pertumuhan selama enam pekan

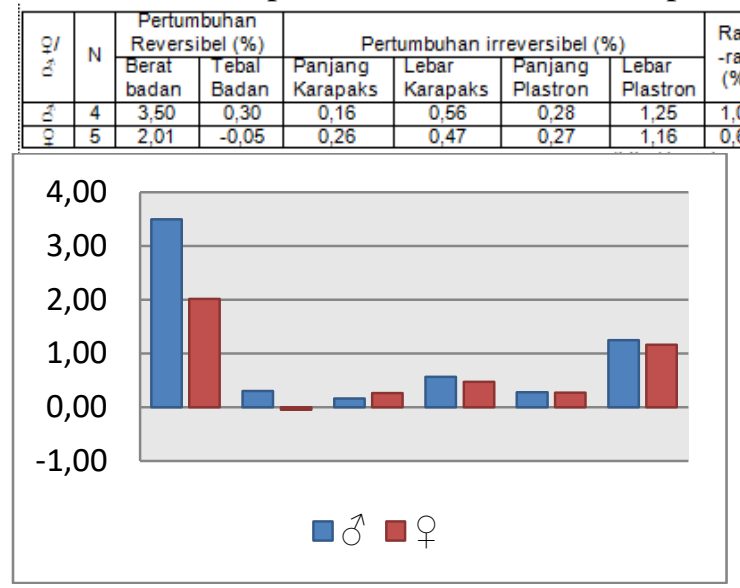

Gambar 7 Rerata Pertumbuhan Kura-kura

Gambar 7 dapat dengan jelas memperlihatkan pertumbuhan kura-kura selama enam baik pertumbuhan reversibel ataupun irreversibel. Dari data yang diperoleh, dapat ditarik kesimpulan bahwa kura-kura memiliki kemampuan beradaptasi dengan baik yang diamati selama enam pekan di Kolam Konservasi UNIB. Berdasarkan rata-rata persen pertumbuhan selama enam pekan terhadap keseluruhan indikator pengamatan, diketahui bahwa S. crassicollis jantan memiliki kemampuan adaptasi yang lebih tinggi dibandingkan $S$. crassicollis betina. Secara umm, baik $S$. crassicollis jantan maupun $S$. crassicollis betina dapat beradaptasi dengan baik dan layak dikonservasi di Kolam Konservasi UNIB.

Hal-hal yang mendukung keberhasilan adaptasi kura-kura di Kolam Konservasi FKIP
UNIB adalah peletakan kura-kura satu ekor di setiap ruang pada kerambah dengan ukuran 1x1 meter sehingga tidak terjadi kompetisi antar individu.Hal ini sejalan dengan pernyataan Maksum (1990), semakin sedikit individu yang bersaing maka ruang yang digunakan akan semakin luas. Semakin luas ruang gerak maka aktivitas individu semakin tinggi.Selain itu, komponen biotik didalam kolam juga mendukung, yaitu terdapat udang tawar dan ikanikan kecil yang juga dapat dijadikan konsumsi oleh kura-kura tersebut.

\section{KESIMPULAN}

Tingkat kemampuan adaptasi $S$. crassicollis jantan lebih tinggi daripada $S$. crassicollis betina. Hal ini terlihat dari rata-rata indikator pertumbuhan selama enam pekan. Dari hasil penelitian diperoleh data bahwa tingkat kemampuan adaptasi $S$. crassicollis jantan dari semua indikator pertumbuhan selama enam pekan sebesar $1,01 \%$, sedangkan $S$. crassicollis betina hanya sebesar $0,69 \%$.

\section{UCAPAN TERIMA KASIH}

Penulis mengucapkan terimakasih secara khusus kepada Partnerships for Enchanced Engagement in Research (PEER) yaitu kerjasama antara Program Pendidikan S2 IPA Universitas Bengkulu dengan University of North Carolina Greensboro (UNCG) dengan tema Developing Science and Learning Research capacity of Bengkulu University in Exsitu Conservastion of Sumateran Fresh Water and Terrestial Turtles yang didukung oleh pihak UNCG, USAID, dan NSF.

\section{DAFTAR PUSTAKA}

Angiletta, Michael J. (2014). Biochemical and PhysiologicalAdaptations.www.thermalad apatation.com.

Casdika E. (1998). Pengaruh salinitas terhadap pertumbuhan tukik penyu hijau Chelonia mydas $L$ di Pantai Pangumbahan Kabupaten Sukabumi [skripsi]. Fakultas Kehutanan. Institut Pertanian Bogor

CITES. (2017). Appendices I, II and III valid from 2 January 2017.

Effendie M I. (1997). Biologi Perikanan. Yogyakarta: Yayasan Pustaka Nusatama 
Erma. (2016). Aklimatisasi Kura-Kura Pipi Putih Di Area Konservasi Kura-Kura Unib dan Pengembangan Bahan Ajar Biologi SMA. TESIS Program S2 Pendidikan IPA

Iskandar D.T. (2000). Kura-kura dan Buaya Indonesia dan Papua Nugini. Jurusan Biologi, Fakultas Biologi dan Ilmu Pengetahuan Alam, IPB. Bandung.

Kurniati H, W. Crampton, A. Goodwin, A. Lockett dan S. Sinkins. (2000). Herpetofauna diversity of Ujung Kulon National Park: An Inventory results in 1990. Journal of Biological Researches

Maksum. (1990). Pengaruh umur dan padat penebaran terhadap pertumbuhan tukik penyu hijau (Chelonia mydas L.) di dalam wadah jaring di Teluk Rajegwesi Taman Nasional Meru Betiri [skripsi]. Bogor: Fakultas Kehutanan. Institut Pertanian Bogor.

Melinda E. (2007). Pengaruh Rasio Kubis Putih Dan Rucah Ayam Sebagai Pakan Serta Pengaruhnya Terhadap Pertumbuhan Kura-Kura Garis Hitam. Skripsi FKIP UNIB: Universitas Bengkulu.
Pasaribu Julita, Ruyani A, Suhartoyo H. (2017). Adaptaion study of Siebenrockiella crassicollis in ex-situ conservation Pond of University of Bengkulu. Bengkulu International Conference on Sience and Education (BICSE-217). 36-39. Bengkulu, 14 Desember 2017; Fakultas Keguruan dan Pendidikan Universitas Bengkulu.

Ruyani A. (2015). Uji daya klimatisasi Siebenrockiella crassicollis terhadap air kolam sebagau upaya konservasi ex-situ di kampus UNIB..Bengkulu: Universitas Bengkulu.

Tjakrawidjaja, A. H. (2010). Studi Fauna Eksotik Ikan Air Tawar, Reptilia dan Amphibia Asli Indonesia. LIPI. Bogor.

Wardiatno Y., Kusrini, M.D., Rahmi, N., dan Masher, A. (2009). Pertumbuhan Juvenil Labi-Labi, Armyda cartilaginea (BODDAERT, 1770) dengan Jenis pakan Berbeda di Desa Belawa, Kabupaten Cirebon.Journal of Tropical Fisheries IPB Indonesia. 